\title{
Effect of Spacing and Training on Growth and Yield of Polyhouse Grown Hybrid Cucumber (Cucumis sativus L.)
}

\author{
Diviya Sharma, V.K. Sharma and Anjali Kumari* \\ Department of Crop Improvement, College of Agriculture, CSKHPKV Palampur (H.P.), India \\ *Corresponding author
}

\begin{tabular}{|l|}
\hline Key w o r d s \\
Hybrid cucumber, \\
Growth and yield, \\
Spacing, Training \\
\hline Article Info \\
\hline Accepted: \\
16 April 2018 \\
Available Online: \\
10 May 2018 \\
\hline
\end{tabular}

\section{Introduction}

Cucumber (Cucumis sativus L.) belonging to family Cucurbitaceae is a warm season vegetable, grown throughout the world under tropical and subtropical conditions. It is said to be the native of northern India (Pursglove, 1969). Cucumber is thought to have originated in India (Harlan, 1975) because of the fact that Cucumis sativus var. hardwickii progenitor of
The present investigation was conducted during off season 2015 at the Research Farm of Department of Agricultural Engineering, College of Agriculture, CSKHPKV, Palampur, Himachal Pradesh to study the effect of different levels of spacing and training on growth and yield of hybrid cucumber under polyhouse. The experiment was laid out following factorial randomized block design (RBD) with three replications. The experiment was comprising of total 18 treatment combinations of two hybrids viz., Kian and Isetis, three level of spacing viz., $60 \times 30 \mathrm{~cm}(\mathrm{~S} 1), 60 \times 45 \mathrm{~cm}(\mathrm{~S} 2)$ and $60 \times 60 \mathrm{~cm}(\mathrm{~S} 3)$ with three level of training viz., T1 (removal of one shoot), T2 (removal of two shoots) and T3 (removal of three shoots). Hybrid Isetis was significantly superior over Kian with respect to vine length $(261 \mathrm{~cm})$, number of fruits per vine $(26.8)$, fruit length $(17.8 \mathrm{~cm})$, fruit weight $(173.53 \mathrm{~g})$, harvest duration () and fruit yield per plant $(3.68 \mathrm{~kg}$ ) with maximum net returns (Rs. 28940.5) and benefit: cost ratio (2.34). Spacing S3 was best in regards to vegetative and yield attributing traits. Higher fruit length $(17.0 \mathrm{~cm})$, fruit breadth $(6.2 \mathrm{~cm})$, fruit weight $(187.51 \mathrm{~g})$, number of fruits per vine $(27.2)$, total soluble solids $\left(3^{0} \mathrm{brix}\right)$, fruit yield per plant $(3.97 \mathrm{~kg}$ ) was observed in S3 and also it took lesser number of days for initiation of first female flower (14.17), lower nodal position of first female flower and days to first picking (33.9). Among the treatments of training, T1 was superior resulting in higher fruit length $(16.7 \mathrm{~cm})$, fruit breadth $(6.0 \mathrm{~cm})$, fruit weight $(179.95 \mathrm{~g})$. Maximum total yield per vine $(4.96 \mathrm{~kg})$ was recorded in treatment combination S3T3. The highest net return and benefit: cost ratio was recorded for hybrid Isetis with treatment S1T3. 
susceptible. Production of cucumber in India is mainly restricted to open field cultivation. Nevertheless, biotic and abiotic stresses are the main factor responsible for low yield and poor quality under open field cultivation particularly during rainy season crop. The protected vegetable cultivation technology can be utilized for year round production of high value quality vegetable crops, with high yield. Increased harvesting efficiency and greater yields, improved pest management, straighter fruits and more number of plants per acre due to closer rows are major advantages of adequate spacing and training; these are of vital importance for healthy and luxuriant growth of crop plants.

Greenhouse production technology of hybrid cucumber emphasizes the need for proper density in order to boost up the production per unit area by utilizing the available space and nutrients applied. There is need to assess the optimum plant density for its cultivation in polyhouses in various regions. An appropriate training system will not only facilitate better management and uniform light to the plants but also permit closer planting, early ripening of fruits, higher yield of larger sized fruits and higher yield of good quality seeds (Lal et al., 2014).

Training methods vary with different growth habits of cucumber cultivars and for different plant densities. Plant density and shoot pruning contribute to marketable yield in the various ways such as plant's ability to obtain the sun light needed for growth and adequate air movement around the plant to reduce risk of fungus and insect problems. Manipulation of canopy architecture through pruning and training together with appropriate spatial arrangements has been identified as key management practices for getting maximum marketable yields from greenhouse crops (Premalatha et al., 2006). Therefore, keeping above mentioned facts in view the present study was carried out to study the effect of different levels of spacing and training on growth and yield of hybrid cucumber under polyhouse.

\section{Materials and Methods}

The present investigation was conducted during off season 2015 at the Research Farm of Department of Agricultural Engineering, College of Agriculture, CSKHPKV, Palampur, Himachal Pradesh. The size of the polyhouse was $20 \times 12 \mathrm{~m}$ (240 sq.m) covered with aluminate sheet and ultra violet stabilized low density polyethylene sheet having 200 micron thickness. The experiment was comprising of total 18 treatment combinations of two hybrids viz., Kian and Isetis, three level of spacing viz., $60 \times 30 \mathrm{~cm}(\mathrm{~S} 1), 60 \times 45 \mathrm{~cm}(\mathrm{~S} 2)$ and $60 \times 60 \mathrm{~cm}(\mathrm{~S} 3)$ with three level of training viz., T1 (removal of one shoot), T2 (removal of two shoots) and T3 (removal of three shoots).

The experiment was laid out following randomized block design (RBD) with three replications. Observations were recorded for 17 different characteristics related to vegetative, yield and quality attributing traits. These observations were vine length $(\mathrm{cm})$, internodal length $(\mathrm{cm})$, number of days taken to anthesis of first female flower, nodal position of first female flower, days to 50 per cent flowering, number of days to first picking, harvest duration, number of fruits per plant, fruit weight $(\mathrm{g})$, fruit length $(\mathrm{cm})$, fruit breadth $(\mathrm{cm})$, fruit yield per vine $(\mathrm{kg})$, fruit yield $\left(\mathrm{kg} / 100 \mathrm{~m}^{2}\right)$, total soluble solids, available nitrogen, available phosphorus and available potassium. The economics of different treatments were determined on the basis of prevailing market price of inputs and produce. The data recorded for various characters were subjected to statistical analysis using Cochren and Cox (1963) method. 


\section{Results and Discussion}

The data pertaining to various yield and yield contributing traits used for evaluation of the treatments were statistically analyzed to test their significance and results of these data have given below:

\section{Growth and development studies}

Results (Table 1) showed that maximum vine length was recorded in hybrid Isetis $(261 \mathrm{~cm})$, $\mathrm{S} 1(227.3 \mathrm{~cm})$ and $\mathrm{T} 1(229.8 \mathrm{~cm})$. Similar observations were also reported by Devi and Gopalkrishnan (2004), Khalid (2010), Bahlgerdi et al., (2014), Jaffar and Wahid (2014) and Rawat et al., (2014). Interaction effects of hybrid, spacing and training showed non-significant effect on vine length. Internodal length determines the height and number of nodes per plant. The parthenocarpic cucumber hybrids bear fruits at almost every node. Therefore, plants having less internodal length and more number of nodes are desired for getting higher yield. Results revealed that the hybrids could not exhibit a significant effect on internodal length while the effect of various levels of spacing and training were significant for intermodal length. Similar findings between the hybrids were also reported by Kumar et al., (2008) and Dogra (2012).

Minimum internodal length (Table 1) was shown by Hybrid Isetis $(9.5 \mathrm{~cm}), \mathrm{S} 3(9.4 \mathrm{~cm})$ and $\mathrm{T} 1$ training system $(9.3 \mathrm{~cm})$. Similar findings were reported by Hao et al., (2010) and Nweke et al., (2013). Interaction effects of hybrid, spacing and training showed nonsignificant effect on intermodal length. Days taken to initiate first female flower is an important character and an indicator of getting early and uniform yield of cucumber grown under protected conditions. Earliest flower initiation (Table 1) was achieved by Hybrid Isetis (14.17), S3 (14.31) and one shoot i.e. T1
(14.56 days). This might be due to availability of good sunshine and nutrients in the soil resulting in the accumulation of more photosynthates and induction of early flowering compared to closer spacing that the length of main shoot grew faster than two and three shoot plants. Data clearly indicated nonsignificant influence of interaction effect of hybrid, spacing and training on days taken to initiate first female lower. Nodal position of first female flower is an important character in cucumber. Appearance of first female flower at the lowest node signifies early entry of cucumber into reproductive phase with capability of longer harvest duration by the plant and further gives early yield. Results revealed that the nodal position of first female flower was significantly influenced by the hybrids.

Female flower appeared at lower nodes (Table 1) in hybrid Isetis (3.88), S3 (4.32) and in plants trained to only one shoot i.e. T1 (4.17). The effect of interactions was not significant for nodal position of first female flower. Results indicated that hybrid Isetis was earliest in achieving 50 per cent flowering stage (26.8 days). Days to 50 per cent flowering (Table 1) was earliest at S3 (26.4 days) and T1 (26.6 days). The results are in close conformity with the findings of Jaffar and Wahid (2014).

The effect of interaction was not significant for days to 50 percent flowering. Number of days to first picking (Table 1) was significantly lesser for hybrid Isetis (33.9) and T1 (35.1). The significant differences among the hybrids for days to first picking have also been observed by Bisht et al., (2010), Gaikwad et al., (2011), Rawat et al., (2014) and Singh et al., (2012) in greenhouse who reported varietal variation among the cucumber hybrids. Plant spacing did not have any significant effect on days to first picking. The interaction under study could not influence number of days to first picking. 
Table.1 Effect of spacing and training on vegetative, yield and quality attributes of polyhouse grown cucumber

\begin{tabular}{|c|c|c|c|c|c|c|c|c|c|c|c|c|c|c|c|c|c|}
\hline 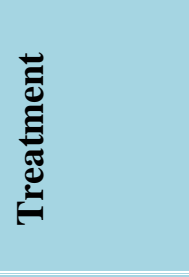 & 氞 & 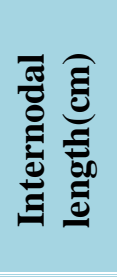 & 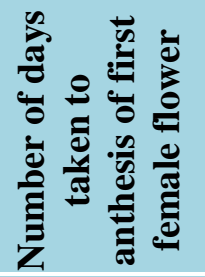 & 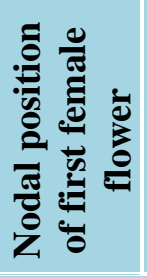 & 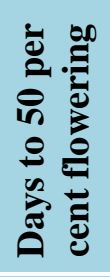 & 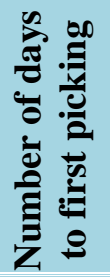 & 离 & 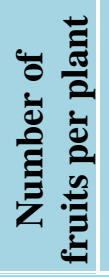 & 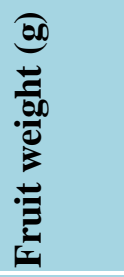 & है & 韋 & 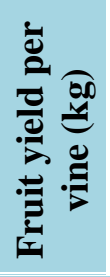 & 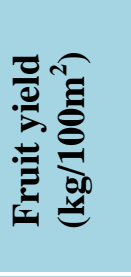 & 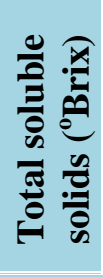 & 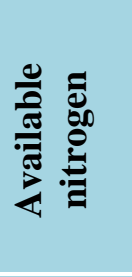 & 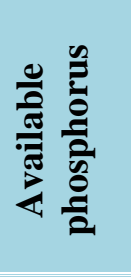 & 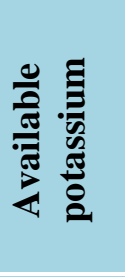 \\
\hline \multicolumn{18}{|l|}{ Hybrid } \\
\hline Kian (V1) & 169.9 & 9.6 & 16.37 & 5.79 & 28.8 & 38.2 & 48.4 & 20.3 & 161.81 & 14.6 & 5.5 & 2.60 & 932.8 & 2.69 & 266.74 & 17.80 & 217.80 \\
\hline Isetis (V2) & 261.0 & 9.5 & 14.17 & 3.88 & 26.8 & 33.9 & 55.5 & 26.8 & 173.53 & 17.8 & 6.2 & 3.68 & 1378.6 & 3.12 & 266.61 & 17.51 & 217.51 \\
\hline $\mathrm{CD}$ at $5 \%$ & 2.1 & NS & 0.71 & 0.57 & 1.0 & 0.5 & 0.5 & 0.3 & 1.74 & 0.1 & 0.08 & 0.15 & 45.3 & 0.03 & NS & NS & NS \\
\hline \multicolumn{18}{|l|}{ Spacing (S) } \\
\hline $\begin{array}{c}\mathrm{S} 1 \\
(60 \times 30 \mathrm{~cm})\end{array}$ & 227.3 & 9.7 & 16.67 & 5.43 & 28.6 & 35.9 & 51.7 & 19.5 & 149.32 & 15.5 & 5.5 & 2.37 & 1305.5 & 2.80 & 264.30 & 16.97 & 216.97 \\
\hline $\begin{array}{l}\mathrm{S} 2 \\
(60 \times 45 \mathrm{~cm})\end{array}$ & 220.1 & 9.6 & 14.83 & 4.75 & 28.3 & 36.0 & 51.8 & 23.9 & 166.18 & 16.1 & 5.9 & 3.07 & 1105.5 & 2.91 & 266.90 & 17.62 & 217.62 \\
\hline $\begin{array}{l}\text { S3 } \\
(60 \times 60 \mathrm{~cm})\end{array}$ & 199.0 & 9.4 & 14.31 & 4.32 & 26.4 & 36.2 & 52.2 & 27.2 & 187.51 & 17.0 & 6.2 & 3.97 & 1056.1 & 3.00 & 268.83 & 18.36 & 218.36 \\
\hline $\mathrm{CD}$ at $5 \%$ & 2.6 & 0.2 & 0.86 & 0.70 & 1.2 & NS & NS & 0.3 & 2.13 & 0.2 & 0.09 & 0.18 & 55.4 & 0.03 & 1.05 & 1.01 & 1.01 \\
\hline \multicolumn{18}{|c|}{ Training (T) } \\
\hline $\mathrm{T} 1$ & 229.8 & 9.3 & 14.56 & 4.17 & 26.6 & 35.1 & 52.8 & 20.7 & 179.95 & 16.7 & 6.0 & 2.27 & 820.7 & 2.88 & 268.83 & 18.37 & 218.37 \\
\hline $\mathrm{T} 2$ & 214.7 & 9.6 & 14.72 & 4.83 & 27.4 & 35.9 & 51.9 & 23.6 & 166.62 & 16.3 & 5.9 & 3.22 & 1196.0 & 2.92 & 265.65 & 17.65 & 217.65 \\
\hline $\mathrm{T} 3$ & 201.9 & 9.8 & 16.53 & 5.50 & 29.3 & 37.1 & 50.9 & 26.3 & 156.44 & 15.6 & 5.6 & 3.92 & 1450.4 & 2.91 & 265.55 & 16.94 & 216.94 \\
\hline $\mathrm{CD}$ at $5 \%$ & 2.6 & 0.2 & 0.86 & 0.70 & 1.2 & 0.6 & 0.7 & 0.3 & 2.13 & 0.2 & 0.09 & 0.18 & 55.4 & NS & 1.05 & 1.01 & 1.01 \\
\hline
\end{tabular}


Table.2 Interaction effect of hybrid and training systems on harvest duration

\begin{tabular}{|c|}
\hline Hybrid \\
\hline Kian \\
\hline Isetis \\
\hline $\mathrm{CD}(\mathbf{P}=\mathbf{0 . 0 5})$ \\
\hline
\end{tabular}

\begin{tabular}{|c|c|c|}
\hline \multicolumn{3}{|c|}{ Training system } \\
\hline One shoot & Two shoots & Three shoots \\
\hline 49.9 & 47.8 & 47.4 \\
\hline 55.7 & 56.1 & 54.4 \\
\hline
\end{tabular}

Table.3 Interaction effect of plant spacing and training systems on number of fruits at final harvest

\begin{tabular}{|c|c|c|c|}
\hline \multirow{2}{*}{ Spacing } & \multicolumn{3}{|c|}{ Training system } \\
\hline & One shoot & Two shoots & Three shoot \\
\hline $\mathbf{6 0} \mathrm{cm} \times \mathbf{3 0} \mathrm{cm}$ & 17.7 & 19.4 & 21.5 \\
\hline $\mathbf{6 0} \mathrm{cm} \times \mathbf{4 5} \mathrm{cm}$ & 20.9 & 23.8 & 27.1 \\
\hline $\mathbf{6 0} \mathrm{cm} \times \mathbf{6 0} \mathrm{cm}$ & 23.7 & 27.6 & 30.3 \\
\hline $\mathbf{C D}(\mathbf{P}=\mathbf{0 . 0 5})$ & & $\mathbf{0 . 6}$ & \\
\hline
\end{tabular}

Table.4 Interaction effect of plant spacing and training systems on fruit weight $(\mathrm{g})$

\begin{tabular}{|c|}
\hline Spacing \\
\hline $60 \mathrm{~cm} \times 30 \mathrm{~cm}$ \\
\hline $60 \mathrm{~cm} \times 45 \mathrm{~cm}$ \\
\hline $60 \mathrm{~cm} \times 60 \mathrm{~cm}$ \\
\hline $\mathrm{CD}(\mathrm{P}=0.05)$ \\
\hline
\end{tabular}

\begin{tabular}{|c|c|c|}
\hline & \multicolumn{3}{|c|}{ Training system } \\
\hline One shoot & Two shoots & Three Shoots \\
\hline 159.31 & 146.66 & 142.01 \\
\hline 179.19 & 168.05 & 151.29 \\
\hline 201.35 & 185.16 & 176.02 \\
\hline
\end{tabular}

Table.5 Interaction effect of plant spacing and training systems on fruit length $(\mathrm{cm})$

\begin{tabular}{|c|c|c|c|}
\hline \multirow{2}{*}{ Spacing } & \multicolumn{3}{|c|}{ Training system } \\
\hline & One shoot & Two shoots & Three Shoots \\
\hline $\mathbf{6 0} \mathrm{cm} \times \mathbf{3 0} \mathrm{cm}$ & 15.8 & 15.6 & 15.1 \\
\hline $\mathbf{6 0} \mathrm{cm} \times \mathbf{4 5} \mathrm{cm}$ & 16.5 & 16.3 & 15.6 \\
\hline $\mathbf{6 0} \mathrm{cm} \times \mathbf{6 0} \mathrm{cm}$ & 17.8 & 17.0 & 16.2 \\
\hline $\mathbf{C D}(\mathbf{P}=\mathbf{0} \mathbf{0 5})$ & & $\mathbf{0 . 3}$ & \\
\hline
\end{tabular}

Table.6 Interaction effect of plant spacing and training systems on fruit yield per plant $(\mathrm{kg})$

\begin{tabular}{|c|}
\hline Spacing \\
\hline $60 \mathrm{~cm} \times 30 \mathrm{~cm}$ \\
\hline $60 \mathrm{~cm} \times 45 \mathrm{~cm}$ \\
\hline $60 \mathrm{~cm} \times 60 \mathrm{~cm}$ \\
\hline$C D(P=0.05)$ \\
\hline
\end{tabular}

\begin{tabular}{|c|c|c|}
\hline \multicolumn{3}{|c|}{ Training system } \\
\hline One shoot & Two shoots & Three Shoots \\
\hline 1.71 & 2.36 & 3.03 \\
\hline 2.33 & 3.11 & 3.78 \\
\hline 2.76 & 4.20 & 4.96 \\
\hline
\end{tabular}


Table.7 Interaction effect of hybrid, plant spacing and training systems on fruit yield $/ 100 \mathrm{~m}^{2}(\mathrm{~kg})$

\begin{tabular}{|c|c|c|c|c|c|c|c|c|c|}
\hline \multirow[t]{3}{*}{ Hybrid } & \multicolumn{9}{|c|}{ Spacing } \\
\hline & \multicolumn{3}{|c|}{$60 \mathrm{~cm} \times 30 \mathrm{~cm}$} & \multicolumn{3}{|c|}{$60 \mathrm{~cm} \mathrm{x} 45 \mathrm{~cm}$} & \multicolumn{3}{|c|}{$60 \mathrm{~cm} \mathrm{x} 60 \mathrm{~cm}$} \\
\hline & $\begin{array}{c}\text { One } \\
\text { shoot }\end{array}$ & $\begin{array}{c}\text { Two } \\
\text { shoots }\end{array}$ & $\begin{array}{l}\text { Three } \\
\text { shoots }\end{array}$ & $\begin{array}{l}\text { One } \\
\text { shoot }\end{array}$ & $\begin{array}{c}\text { Two } \\
\text { shoots }\end{array}$ & $\begin{array}{c}\text { Three } \\
\text { shoots }\end{array}$ & $\begin{array}{l}\text { One } \\
\text { shoot }\end{array}$ & $\begin{array}{c}\text { Two } \\
\text { shoots }\end{array}$ & $\begin{array}{l}\text { Three } \\
\text { shoots }\end{array}$ \\
\hline Kian & 569.8 & 1100.9 & 1304.6 & 524.4 & 903.9 & 1198.4 & 758.4 & 901.8 & 1134.3 \\
\hline Isetis & 1243.6 & 1536.4 & 2078.6 & 1097.6 & 1419.9 & 1490.0 & 731.6 & 1313.1 & 1497.3 \\
\hline $\mathrm{CD}(\mathrm{P}=0.05)$ & & & & & 135.7 & & & & \\
\hline
\end{tabular}

Prolonged harvest duration is an important aspect to catch an early market in one hand and to avoid gluts in the market on the other hand to ensure maximum returns. Results indicated that longer harvest duration (Table 1) was observed in hybrid Isetis (55.5) and $\mathrm{T} 1$ (52.8).

Harvest duration was not influenced significantly by plant spacing. Further results reveal that longest harvest duration was recorded from interaction effect (Table 2) of hybrid Isetis $\times \mathrm{T} 1$ (55.7).

\section{Yield attributes and yield}

Highest number of fruits per vine (Table 1) was recorded in hybrid Isetis (26.8), S3 (27.2) and T3 (26.3). These results are in conformity with Lebedeva and Turlakova (1985), Mohamedien et al., (1993), Muhammad et al., (1998) and Bisht et al., (2010). Further results revealed that maximum number of fruits per vine was recorded from interaction effect (Table 3) of S3T3 (30.3).

Fruit weight plays an important role in fruit production. Higher fruit weight (Table 1) was observed in hybrid Isetis (173.53 g), S3 $(187.51 \mathrm{~g})$ and $\mathrm{T} 1(179.95 \mathrm{~g})$. These results are in conformity with Bisht et al., (2010), Singh et al., (2012), Umekwe (2015) and Aniekwe and Anike (2015). Further results revealed that maximum fruit weight was recorded from interaction effect (Table 4) of S3T1 (201.35).
Longer and broader fruits (Table 1) were observer in hybrid Iseti, S3 and T1. Further results indicated that interaction effect of spacing and training systems was found to be significant for fruit length. Maximum fruit length $(17.8 \mathrm{~cm})$ was obtained in S3T1 combination (Table 5). Interactions under study could not influence fruit breadth significantly.

Higher fruit yield per plant (Table 1) was obtained in hybrid Isetis $(3.68 \mathrm{~kg}), \mathrm{S} 3$ (3.97 $\mathrm{kg})$ and $\mathrm{T} 3(3.92 \mathrm{~kg})$. These results are in close conformity with Bisht et al., (2010), Oga and Umekwe (2015) and Lopez et al., (2015).

The interaction effect (Table 6) between spacing and training systems was found to be significant. Higher fruit yield per plant was observed in S3T3 (4.96 kg).

Higher fruit yield $/ \mathrm{m}^{2}$ (Table 1) was obtained from hybrid Isetis $\left(1378.6 \mathrm{~kg} / \mathrm{m}^{2}\right), \mathrm{S} 1(1305.5$ $\left.\mathrm{kg} / 100 \mathrm{~m}^{2}\right)$ and T3 $\left(1450.4 \mathrm{~kg} / 100 \mathrm{~m}^{2}\right)$. Further results indicated that interaction effect (Table 7) of hybrid Isetis with S1T3 produced higher fruit yield $/ \mathrm{m}^{2}\left(2078.6 \mathrm{~kg} / \mathrm{m}^{2}\right)$.

\section{Quality evaluation}

Total soluble solids content signifies the amount of sugars present in the fruit juice. Hence high total soluble solids content is desirable for processed products. Higher total soluble solids (Table 1) were recorded in 
hybrid Isetis ( $3.12^{0}$ brix) and S3 (3.00 ${ }^{\circ}$ brix). These results are supported by the work of Nerson (1998). Neither training system nor the interaction effect of hybrids, spacing and training systems had any influence on the TSS content.

\section{Soil analysis}

Hybrids could not exhibit any significant effect on available nitrogen, phosphorus and potassium in soil after the harvest of cucumber crop. Maximum available nitrogen, phosphorus and potassium in soil (Table 1) were observed in $\mathrm{S} 3$ and $\mathrm{T} 1$.

Similar results were also reported by Chand (2014). The interaction between hybrids, plant spacing and training systems failed to significantly influence the available nitrogen, phosphorus and potassium in soil.

\section{Economic studies}

Economic evaluation of treatments revealed that maximum gross returns, net returns and benefit: cost ratio was recorded (Table 1) in hybrid Isetis (Rs. 41358.3, Rs. 28940.5 and 2.34, respectively), S1 (Rs. 39166.3, Rs. 25092.6 and 1.89, respectively) and T3 (Rs. 43513.0, Rs. 30187.9 and 2.33, respectively).

On the basis of results obtained in the present investigation it was concluded that among the various treatment combinations, highest yield and benefit: cost ratio were recorded by treatment combination of hybrid Isetis with S1T3. Hence, treatment combination S1T3 was recommended for getting maximum economic returns. Based on above findings, transplanting of cucumber hybrid Isetis at a spacing of $60 \times 30 \mathrm{~cm}(\mathrm{~S} 1)$ and plants trained to three shoots (T3) can be recommended for growing cucumber in cost effective naturally ventilated polyhouse for higher fruit yield and economic returns.

\section{References}

Aniekwe, N. L. and Anike, N. T. 2015. Effects of Different Mulching Materials and Plant Densities on the Environment, Growth and Yield of cucumber. $J$. Agric. Vet. Sci., 8: 64-72.

AOAC. 1970. Methods of analysis. Association of official agriculture chemists, Washington DC

Bahlgardi, M., Aroiee, H. and Azizi, M. 2014. The study of plant density and planting methods on some growth characteristics, seed and oil yield of medicinal pumpkin (Cucurbita pepo var. styriaca, cv. 'kaki'). Am. J. Life Sci., 2(5): 319-324.

Bailey, L. H. 1969. Mannual of Cultivated Plants. Macmillan Company, New York.

Bisht, B., Singh, M. P., Srivastva, B. K., Singh, Y. V. and Singh, P. K. 2010. Evaluation of open-pollinated varieties and hybrids of cucumber for off-season production under naturally ventilated polyhouse. Ind. J. Hort., 67: 202-205.

Chand, J. A. R. 2014. Nutrient Use Efficiency and Economics of Salad Cucumber Using Drip Fertigation in Naturally Ventilated Polyhouse J. Agric. Vet. Sci., 7(12): 22-25.

Cochran, W. G. and Cox, G. M. 1963. Experimental Designs. Asia Publishing House, Bombay. p 293-316.

Devi, M. J. and Gopalkrishnan, T. R. 2004. Spacing influences growth and productivity of less spreading and short duration oriental pickling melon (Cucumis melo var. common Mak.) cv. 'saubhagya'. J. Trop. Agric., 42(1): 5962.

Dogra, L. K. 2012. Genetic evaluation of some hybrids of cucumber under modified naturally ventilated greenhouse in mid hills of Western 
Himalayas. M.Sc. Thesis, CSKHPKV, Palampur.

Gaikwad, A. G., Sonawane, H. G., Dhumal, S. S. and Musmade, A. M. 2011. Variability studies in cucumber (Cucumis sativus L.). Asian J. Hort., 6(1): 121-125.

Hao, X., Wen, G., Papadopoulos, A. P. and Khosla, S. 2010. A twin-head "V" High -wire greenhouse cucumber production system for reducing crop start-up costs. Hort Tech., 20(6): 963-970.

Harlan, J. R. 1975. Crops and Man. American society of Agronomy, Crop Science Society of America, Madison, WI.

Jaffar, A. and Wahid, F. 2014. Effect of row spacing on growth, yield and yield components of cucumber varieties. Science Letter, 2: 33-38.

Khalid, A. A. S. 2010. Growth and yield of some cucumber cultivars as affected by plant density and royal jelly application. J. Hort. Sci. and Ornamental Pl., 2(2): 131-137.

Kumar, A., Kumar, S. and Pal, A. K. 2008. Genetic variability and characters association for fruit yield and yield traits in cucumber. Indian J. Hort., 65(4): 423-428.

Lal, M., Kanwar, H. S. and Kanwar, R. 2014. Impact of spacing and training on seed yield of capsicum, Capsicum annuum L. under protected conditions. Int. J. Farm Sci., 4(3): 42-48.

Lebedeva, A. T. and Turlakova, V. G. 1985. Fruit formation and yield of parthenocarpic cucumber hybrids. Selektsiya ovoshchnykh kul'tur, Moscow, USSR.

Lopez, J., Leon, J. J. and Amafor, B. M. 2015. Production of cucumber (Cucumis sativus L.) depending on the density plantation under greenhouse. European Sci. J., 11: 24.

Mohamedien, S. E. A., Doweny, H. H. and Hashem, M. M. 1993. Response of some cucumber hybrids to plasticulture under Egyptian environmental conditions. Egyptian J. Hort., 18(5): 6371.

Muhammad, F. C. H., Tariq, M., Amanallah, J. and Hidayat, U. 1998. Comparative performance of some cucumber hybrids under plastic tunnel during spring summer and autumn season. Sarhad J. Agric., 14(1): 29-32.

Nerson, H. 1998. Responses of "little leaf" vs. normal cucumber to planting density and chlorflurenol. Hort. Sci., 33: 816818.

Nweke, I. A., Orji, E. C. and Ijearu, S. I. 2013. The effect of staking and plant spacing on the growth and yield of cucumber (Cucumis sativus L.) IOSR J. Env. Sci. Toxic. and Food Tech., 3(4): 26-31.

Oga, I. O. and Umekwe, P. N. 2015. Effects of pruning and plant spacing on the growth and yield of watermelon (Citrullus lanatus L.) in UnwanaAfikpo. Int. J. Sci. Res., 5(4): 110-115.

Premalatha, M. G. S., Wahundeniya, K. B., Weerakkody, W. A. P. and Wicramathunga, C. K. 2006. Plant training and spatial arrangement for yield improvements in greenhouse cucumber (Cucumis sativus L.) varieties. Trop. Agric. Res., 18: 346357.

Pursglove, J. W. 1969. Tropical Crops Dicotyledons Longmans. Green and Corporation Limited London and Herlow.

Rawat, M., Maurya, S. K., Singh, P. K. and Maurya, R. J. 2014. Screening of improved cultivars of cucumber in naturally ventilated polyhouse under tarai condition of Uttrakhand. J. Hill Agric. 5(1): 72-75.

Singh, D. K., Singh, A., Punetha, S. and Singh, B. 2012. Evaluation of some cucumber (Cucumis sativus L.) 
genotypes under protected condition in Uttrakhand-mid hills. National seminar on protected cultivation of vegetables and flowers- A value chain approach. G.B. Pant University of Agriculture and Technology, Pantnagar, Uttrakhand, India. p 11.
Umekwe, P. N., Okpani, F. M. and Okocha, I. O. 2015. Effects of different rates of NPK 15:15:15 and pruning methods on the growth and yield of cucumber (Cucumis sativus L.) in unwana-afikpo. Int. J. Sci. Res., 4(10): 36-39.

\section{How to cite this article:}

Diviya Sharma, V.K. Sharma and Anjali Kumari. 2018. Effect of Spacing and Training on Growth and Yield of Polyhouse Grown Hybrid Cucumber (Cucumis sativus L.). Int.J.Curr.Microbiol.App.Sci. 7(05): 1844-1852. doi: https://doi.org/10.20546/ijcmas.2018.705.217 